\title{
Modified Starch and Its Potentials as Excipient in Pharmaceutical Formulations
}

\author{
Khalid Garba Mohammed* \\ Department of Pharmaceutics and Pharmaceutical Technology, Bayero University Kano, Nigeria
}

Submission: March 24, 2017; Published: April 03, 2017

*Corresponding author: Khalid Garba Mohammed, Department of Pharmaceutics and Pharmaceutical Technology, Bayero University Kano, Nigeria; Tel no: +2347037856445; Email: gmkhalid.pht@buk.edu.ng

Abstract

Despite its vast commercial value, native starch has some inherent weaknesses when it comes to pharmaceutical application, to mention few include; poor compressibility, low flow ability values and often drug/excipient compatibility problems. In this review, some potentials of modified starch with particular emphasis on their improved functionalities and applicability in pharmaceutical formulations were discussed. Basic requirements for pharmaceutical excipients and various modification methods for starch i.e chemical modification, physical and biotechnological methods were highlighted.Pharmaceutical applications of modified starches as tablet super disintegrant, sustained/ controlled release polymer, plasma volume expanders and as directly compressible excipient in tablet formulations have been cited.

Keywords: Starch; Excipient; Pharmaceutical and Formulation

\section{Introduction}

\section{Pharmaceutical excipients}

These are additives used to convert pharmacologically active compounds into pharmaceutical dosage forms suitable for administration to patients [1]. Although excipients are the non-active ingredients, they are essential in the successful production of acceptable solid dosage forms such as tablets and powders. For example, the lack of filling materials would make it exceedingly challenging, if not impossible, to produce a $1 \mathrm{mg}$ dose tablet of a potent drug [2].

For toxicological purposes, it may be more appropriate to define an excipient as any substance other than the active drug or pro-drug which has been appropriately evaluated for safety and is included in a drug delivery system [1].

Excipients are critical to the design of the delivery system and play a major role in determining its quality and performance [3]. They may be selected to enhance stability (antioxidants, UV absorbers), optimize or modify drug release (dis-integrants, hydrophilic polymers, wetting agents, biodegradable polymers), provide essential manufacturing technology functions (binders, glidants, lubricants), enhance patient acceptance (flavors), or aid in product identification (colorants). Thus a pharmaceutical formulation is not a random combination of ingredients, but rather a carefully thought out, rational formulation designed to satisfy the above criteria.
A long list of possible excipients is available to the formulation scientist, but certain external factors such as cost, functional reliability, availability, and international acceptance govern their selection. For example, although the official compendia provide standards for identity and purity of excipients, monographs may not provide tests to assure their functionality.

\section{Reasons for excipients inclusion into dosage forms}

i. Aid processing of the dosage unit during manufacture.

ii. Ease of administration to the target patient population(s) by the intended route and improved dosing compliance

iii. Protect, support, or enhance stability and or bioavailability

iv. Assist in product identification.

v. Enhance any other attribute of the overall safety and effectiveness of the drug product during storage and use [4].

\section{Ideal properties of pharmaceutical excipient}

The following general criteria are essential for excipients which should:

i. Be pharmacologically inert

ii. Be physically and chemically stable 
iii. Have no interference with drug bioavailability;

iv. Have absence of pathogenic microbial organisms; and

v. Be commercially available at relatively low cost [5].

In reality, no single excipient would satisfy all the criteria listed above, therefore, a compromise of the different requirements has to be made at some point. For example, although widely used in pharmaceutical tablet and capsule formulations as a diluents, lactose may not be suitable for patients who lack the intestinal enzyme lactase to break down the sugar, thus leading to the gastrointestinal tract symptoms such as cramps and diarrhea in such patients. The role of excipients varies substantially depending on the individual dosage form [6].

\section{Starch as pharmaceutical excipient}

Starch possesses definite chemical structure and composition. It occurs widely as the major polysaccharide food reserve in seeds, swollen stems, tubers and roots of plants. Starch is present in these plant parts in the form of granule. It is the second most abundant compound synthesized by plant cells after cellulose, and exceeds cellulose in significance in terms of food value. Starch is a polysaccharide of glucose. It is stored in the plants as granules composed of amylose and amylopectin. Starch molecules produced by each plant have specific structures and compositions (for instance the length of glucose chains or the amylose/amylopectin ratio), and the protein content of the storage organs may vary significantly [7].

Starch is composed of very small spherical or elliptical granules. It is colorless, odorless with slight characteristic taste, insoluble in water and alcohol. In pharmaceutical manufacture, starch is an important excipient that has been commonly employed because of its versatility and cheapness [8].

Native starches were well explored as binders and disintegrants in solid dosage forms, but due to poor flow ability, their utilization is restricted. Most common form of modified starch i.e. Pregelatinized starch marketed under the name of starch1500® are nowadays most preferred directly compressible excipients in pharmaceutical industry. Modified rice starch, starch acetate and acid hydrolyzed diascorea, were well established as multifunctional excipients in pharmaceutical industry [9].

\section{Sources of Starch}

Starch is found in cereals and seeds (like corn, maize, wheat, rice, sorghum, barley, or peas) and in tubers or roots (like potato or cassava) of plants. Most of the starch produced worldwide is derived from corn, but other types of starch such as cassava, sweet potato, potato, and wheat starch are also produced in large amounts [9].

\section{Extraction of starch}

The wet milling is the standard method of extracting pure starch from the raw material. After removing the impurities and other debris, separation of pure starch from other undesired components of the raw material like oil, highly-bound proteins and fibers is done through wet milling. When the insoluble starch is collected as its intact granules, it is referred to as native starch. However, at this step, the native starch is wash, dry and keeps for subsequent processing in to modified starches [10].

\section{Molecular structure of starch}

Essentially, the molecular structure is made up of glucose polymers that come in two molecular forms, i.e linear (amylose) formed by $\beta$-1,4-glycosidic linkages, and branched (amylopectin) formed by $\beta$-1,6-glycosidic linkages. While amylose was traditionally thought to be completely unbranched, it is now known that some of its molecules contain a few branch points [11]. Although in absolute mass, only about one quarter of the starch granules in plants consists of amylose, there are about 150 times more amylose molecules than amylopectin molecules. Amylose is a much smaller molecule than amylopectin [11].

\section{Starch granules}

Starch molecules arrange themselves in the plant in semicrystalline granules. Each plant species has a unique starch granular size ranging between $1-100 \mu \mathrm{m}$. Quantitatively, one gram (1g) of starch contains billions of granules and each granule in turn contains trillions of starch molecules. Starch becomes soluble in water when heated. The granules swell and burst, the semi-crystalline structure is lost and the smaller amylose molecules start leaching out of the granule, forming a network that holds water and increasing the mixture's viscosity [12].

\section{Starch products (Types of Starch)}

The starch molecule can be extracted and sold as such (native starch), but it can also undergo several processing operations in order to improve its proprieties and enlarge the range of its uses.

Native starch is the starch chain extracted from raw material, in its original form. It can either be dried (powder) or not (liquid starch). Unmodified starches have limited usage due to their inherent weakness of hydration, swelling and structural organization [13].

Modified starch on the other hand is a native starch that undergoes some changes by chemical, physical and or biotechnological means. Modifications on starches are carried out to enhance some physico chemical properties like viscosity, texture, stability, flow ability among many desired functional properties for many industrial applications. The overall aim of such modification in pharmaceutical solid dosage forms is to have a good flow ability and compressibility [9].

Official starches available recommended by British Pharmacopoeia [14] for pharmaceutical applications include:

i.Maize starch obtained from caryopsis of Zea mays L.

ii.Potato starch obtained from tuber of Solanumtuberosum L. 
iii. Rice starch obtained from caryopsis of Oryza sativa L.

iv. Tapioca starch obtained from the tuber of Manihotutilissima.

v. Wheat starch obtained from caryopsis of Triticumaestivum, L (T.vulgare)

\section{Modification of starch}

Starch modification can be introduced by altering the structure including the hydrogen bonding in a controlled manner to enhance and extend their application in industrial prospective. The modification takes place at the molecular level and can be chemical, physical or enzymatic. Modified starches are typically used in food and pharmaceutical systems around the globe [11].

\section{Types of modified starches}

Most native starches for use in industry are modified in controlled manner. They can be summarized as follows:-

\section{Chemical modification of starch}

Cross-linking: Cross linking is the most important modified form that finds use in Industry. It involves replacement of hydrogen bond present between starch chains by stronger, permanent covalent bonds. Distarch phosphate or, adipate are the most commonly used cross-linked starch. Cross-linked starches offer acid, heat and shear stability over the native starch [15].

Stabilization: This process is used in conjunction with cross-linking. Stabilization is used to enhance shelf life through tolerance to temperature fluctuations [16].

Conversion: This is collective term for a range of chain cleavage reactions of starch. Typically includes acid hydrolysis, enzyme hydrolysis and oxidation [1].

Acid hydrolysis: Acid reacts and de-polymerizes the amorphous regions of the granules such that when the starch is heated beyond its gelatinization temperature, the granules rupture quickly. This result in a hot lower viscosity cooked starch which becomes a stronger gel on cooking compared to the native parent starch [17].

Enzyme hydrolysis: Starch modified with amylase enzyme produces derivative with good adhesion property. The extent of enzyme hydrolysis determines the range of chain length produced such as glucose, maltose, oligosaccharides and polysaccharides. $\alpha$-amylases selectively and randomly attacks the 1,4-linkages of the starch to produce maltodextrins[18].

Oxidation: This is obtained by reacting the native starch with sodium hypochlorite or peroxide. Oxidized starch products are mainly used as surface sizing agent or coating binder and available in different viscosity grade [19].

\section{Physical Modification of Starch}

Pregelatinization of starch: It is the simplest starch modification, prepared by heating the slurry, roll drying, spray drying or, extrusion process. It maintains starch integrity while improving cold water thickening. This process is designed to enhance adhesiveness of starches. Pregelatinized starches exhibit good flow, binding and compressibility [20], and therefore enhanced their pharmaceutical acceptability.

Annealing: This is carried out by soaking the native starch in excess water between 40 to $60 \% \mathrm{w} / \mathrm{w}$ between gelatinization temperatures for a specific period of time. Annealed starch has decreased swelling characteristics [21], and the resultant enhanced crystalline structure does not rupture the starch granules [22].

Applications of Modified starches in Pharmaceuticals and Medical Industries: In recent years, pharmaceutical companies around the world widely use modified starches of various kinds in various stages of drug production or development technology. Excipient plays a very important role in solid dosage formulation by imparting mechanical strength, stability and tablet disintegration properties.

\section{Tablet Superdisintegrant}

Modified starches are generally employed for immediate release tablet formulations, where drug should be available within short span of time to the absorptive areas. Sodium carboxymethyl starch, which is well established and marketed as sodium starch glycolate is generally used for immediate release formulation [23].

\section{Controlled/Sustained release polymer}

Two decades earlier modified starch was first evaluated as sustained release polymer. Modified starches in different forms such as Grafted, acetylated and phosphate ester derivatives have been extensively evaluated for sustaining the release of drug for better patient compliances [24].

\section{Plasma volume expander}

Starch modified with ethylene oxide produces hydroxy ethyl starch, which is now mainly used as plasma volume expander. This is mainly useful for the patients suffering from trauma, heavy blood loss and cancer treatment.

\section{Directly compressible excipient in tablet formulation}

Recently, Khalid et al, reported that acid hydrolyzed modified starch of Plectranthusesculentus produced a promising directly compressible filler/binder that can be substituted for microcrystalline cellulose (MCC PH 101) in conventional tablet formulations. It produces the metronidazole tablets of better quality in terms crushing strength and friability and also drugrelease profile with regards to disintegration and dissolution parameters comparable to that of MCC PH 101 [25]. 


\section{Conclusion}

Starches from different sources have found application in Pharmaceutical formulations both native and in modified form. However, there are still abundant untapped starches from various natural sources that need little technical modifications to qualify them suitable as potential Pharmaceutical excipient. This therefore requires effective collaboration between researchers in the academia and pharmaceutical industries for proper translation of laboratory findings into commercialization of such products.

\section{References}

1. Wade A, Weller PJ (1994) Handbook of Pharmaceutical Excipients, American Pharmaceutical Association and the Pharmaceutical Press. London, UK, pp: 355-361.

2. Klevan I (2011) Compression Analysis of Pharmaceutical Powders: Assessment of Mechanical Properties and Tablet Manufacturability Prediction. University of Troms $\varnothing$, Norway.

3. Chowhan ZT (1998) Tablet Ingredients and their role in formulations. FMC Corporation, USA, pp. 1-18.

4. Blecher L (1993) Excipients: the important components. Pharmaceutical Process and innovations.

5. Armstrong NA (1989) Time-dependent factors involved in powder compression and tablet manufacture. International Journal of Pharmacy 49(1): 1-13.

6. Gowtham K, Dokala CP (2013) Direct compression- An overview. International Journal of Research in Pharmaceutical and Biomedical Sciences.

7. Khalid GM, Musa H, Olowosulu AK (2015) Compaction and Compressibility Evaluation of Modified Starches Derived from Plectranthusesculentus by Direct Compression. American Journal of Pharmtech Research 5(6): 354-365.

8. Muazu J, Girbo A, Usman A, Mohammed GT (2012) Preliminary studies on Hausa potato starch I: The disintegrant properties. Journal of Pharmaceutical Science and Technology 4(3): 883-891.

9. Bos CE, Bolhuis GK, Lerk CF, Duineveld CAA (1992) Evaluation of Modified rice starch: A New Excipient for Direct Compaction. Drug Development and Industrial Pharmaceutics 18(1): 93-106.
10. Whistler R, Be Miller J (2009) In: Starch chemistry and Technology (3 $3^{\text {rd }}$ edn), Academic Press, New York, USA.

11. Light JM (1990) Modified food starches: Why, what, where and how. Cereal Foods World 35: 1081.

12. Stryer L, Berg JM, Tymoczko JL (2002) Biochemistry ( $5^{\text {th }}$ edn), In: Freeman WH (Ed.), San Francisco, USA.

13. Eliasson AC (2004) Starch in Food, Processing and values in the $21^{\text {st }}$ Centuary. Wood head Publishing Limited, UK.

14. British Pharmacopoeia (2009) Vol. 1 and II: Her Majesty's Stationery Office, University Press, Cambridge, England.

15. Huijbrechts AML (2008) Multifunctional Starch Derivatives: Synthesis, Characterisation and Properties. Ph.D Thesis. University in Wageningen, Netherlands, pp: 135.

16. Lee MH, Baek MH, Cha DS, Park HJ, Lim ST (2002) Freeze-thaw stabilization of sweet potato starch gel by polysaccharide gums. Food hydrocolloids 16(2002): 345-352.

17. Jacobs AL (1985) Determining optimum drug/excipient compatibility through preformulation testing. Pharmaceutical Manufacture 2(6): 43.

18. Chiu CW, Huang DP, Kasica JJ, Xu JF (1997) United States of America/ US Patents: 5599569.

19. Forssell P, Hamunen A, Autio K, Poutanen K (1995) Starch and its derivatives/starke pp. 47:37.

20. Joshi AA, Neves S (2005) "From commodities to specialized excipients", Pharmaceutical Technology pp. 68-71.

21. Tester RF, Debon SJJ, Karkalas J (1998) Annealing of Wheat Starch. Journal of Science 28(3): 259-272.

22. Oladebeye AO, Oshodi AA, Oladebeye AA, Amoo IA (2011) Pasting Properties of Heat-Moisture Treated Starch of White and Yellow Yam (Dioscoreaspacie) Cultivars. Nature and Science 9(1): 29-33.

23. Nattapulawat A, Purkkao N, Suwithayapanth O (2009) AAPS Pharmaceutical Science and Technology 10(1): 193-198.

24. Rowe RC, Sheskey PJ, Owen SC (2006) Handbook of Pharmaceutical Excipients. ( $5^{\text {th }}$ edn), Pharmaceutical Press and the American Pharmacists Association 32(8): 725-730.

25. Khalid GM, Musa H, Olowosulu AK (2016) Evaluation of Filler/Binder Properties of Modified Starches Derived from Plectranthusesculentus by Direct Compression in Metronidazole Tablet Formulations. Pharm Anal Acta 7(1): 74.

\begin{tabular}{l} 
Your next submission with Juniper Publishers \\
will reach you the below assets \\
- Quality Editorial service \\
- Swift Peer Review \\
- Reprints availability \\
- E-prints Service \\
- Manuscript Podcast for convenient understanding \\
- Global attainment for your research \\
- Manuscript accessibility in different formats \\
( Pdf, E-pub, Full Text, Audio) \\
- Unceasing customer service \\
Track the below URL for one-step submission \\
https://juniperpublishers.com/online-submission.php \\
\hline
\end{tabular}

